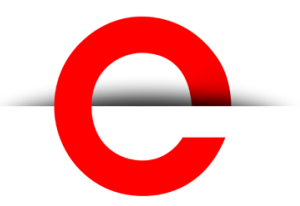

U T S

e PRES S
PORTAL Journal of

Multidisciplinary

International Studies

Vol. 13, No. 2

July 2016

Designing Futures in Indonesia, Curated Works Special Issue, Curated by Alexandra Crosby.

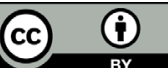

(C) 2016 by Campbell Drake and William Kelly. This is an Open Access article distributed under the terms of the Creative Commons Attribution 4.0 Unported (CC BY 4.0) License (https:// creativecommons.org/ licenses/by/4.0/J, allowing third parties to copy and redistribute the material in any medium or format and to remix, transform, and build upon the material for any purpose, even commercially, provided the original work is properly cited and states its license.

Citation: Drake, C. and Kelly, W. 2016. Sustainable Tourist Development in Rote Ndao. PORTAL Journal of Multidisciplinary International Studies, 13:2, 1-18. http:// dx.doi.org/10.5130/portal. v13i2.5026

ISSN 1449-2490 | Published by UTS ePRESS I http://portal. epress.lib.uts.edu.au
CURATED WORK

\section{Sustainable Tourist Development in Rote Ndao}

\author{
Campbell Drake, William Kelly
}

School of Design, Faculty of Design, Architecture and Building, University of Technology Sydney

Corresponding author: Campbell Drake, School of Design, Faculty of Design, Architecture and Building, University of Technology Sydney, PO Box 123, Broadway NSW 2007, Australia. campbell.drakeduts.edu.au

DOI: http://dx.doi.org/10.5130/portal.v13i2.5026

Article History: Received 20/06/2016; Revised 27/06/2016; Accepted 11/07/2016;

Published 09/08/2016

\begin{abstract}
Located in the eastern province of Nusa Tenggara Timur (West Timor), Rote Ndao is an island of 120,000 residents that can be accessed via ferry from the West Timorese capital of Kupang. Prior to East Timorese independence in 2002, Kupung saw direct international flights from Australia, since redirected through Bali and Jakarta. Rote Ndao is traditionally focused on subsistence farming and the harvesting of the Lontar Palm; however, recent years have seen an influx of foreign interest as domestic and international investors buy up large tracks of beach front property. White sand beaches and world class surfing, Rote is a quintessential island paradise and many are predicting that this remote part of eastern Indonesia will become the new Bali of the 21st century.
\end{abstract}

\section{Keywords}

Sustainable Design; ecotourism; Rote Ndao; Indonesia; ecodesign: tourism 
U T S

e PRE S S

Located in the eastern Indonesian province of Nusa Tenggara Timur (West Timor), Rote Ndao is an island of 120,000 residents that can be accessed via ferry from the West Timorese capital of Kupang. Prior to East Timorese independence in 2002, Kupung saw direct international flights from Australia, since redirected through Bali and Jakarta. Rote Ndao is traditionally reliant on subsistence farming and the harvesting of the Lontar Palm; however, recent years have seen an influx of foreign interest as domestic and international investors buy up large tracts of beach-front property. With white sand beaches and world class surfing, Rote is a quintessential island paradise and many are predicting that this remote part of eastern Indonesia will become the new Bali of the 21st century.

Common in the fast-paced roll out of speculative tourism development in Indonesia is a tendency to import inexpensive building materials and labor from more industrialized regions of the archipelago. Advocating an alternate design process in which building materials, construction methodologies and labor are sourced locally, the following collection of photographs is the byproduct of a study that took place into sustainable design strategies for tourism development on the Island of Rote in 2015.

Focusing on the impact of foreign investment on the cultural fabric of Rote Ndao, this study investigates how sustainable design practices can provide tangible benefits to the conditions and wellbeing of local communities, cultural practices and environments. In focusing on environmental, social and economic sustainability, twelve resorts and adjacent local houses were audited to identify and evaluate the relationship between foreign owned resorts and private villas and that of local Rotenese communities and businesses. Through the lens of sustainable design, the criteria for carrying out these audits included spatial composition, landscaping, construction methodology, building materials, ownership, management, staffing, price points, sanitation and the supply of power and water. Complementary to the audits, twelve transects ${ }^{1}$ were produced by cutting a section from the road to the beach through each of the twelve resorts and adjacent local houses. A transect is a method for making observations and taking measurements by drawings a straight line or narrow section through a natural feature or across the earth's surface. The results of combining the twelve audits and transects reveal a range of environmental, social and economic concerns relative to sustainable tourism development in West Rote.

Summarizing the findings of the study, tangible benefits for economic sustainability include the local ownership of tourism developments and the provision of employment and hospitality training for local community members. Strengths within sustainable environmental design included the retention of existing vegetation as a device for passive shading, the importance of master planning with which to carefully consider the location of buildings relative to passive cross ventilation, views and noise transfer, solar energy as the preferable, renewable source of power and ceiling fans over energy consumptive air conditioning. Social attributes of the study suggest extended interaction between guests and local community members situating resorts away from the beach front.

Whilst the audits and transects provide a valuable resource in tracking the current state of development in this region of Rote, perhaps equally important was the opportunity for open discussion between local and expatriate community members at the forum provided by the presentations at the Anugerah Resort. Those attending the presentations included government

1 Audits and transects were produced by twelve interior and spatial design students from the University of Technology Sydney. 
U T S

e P R E S S

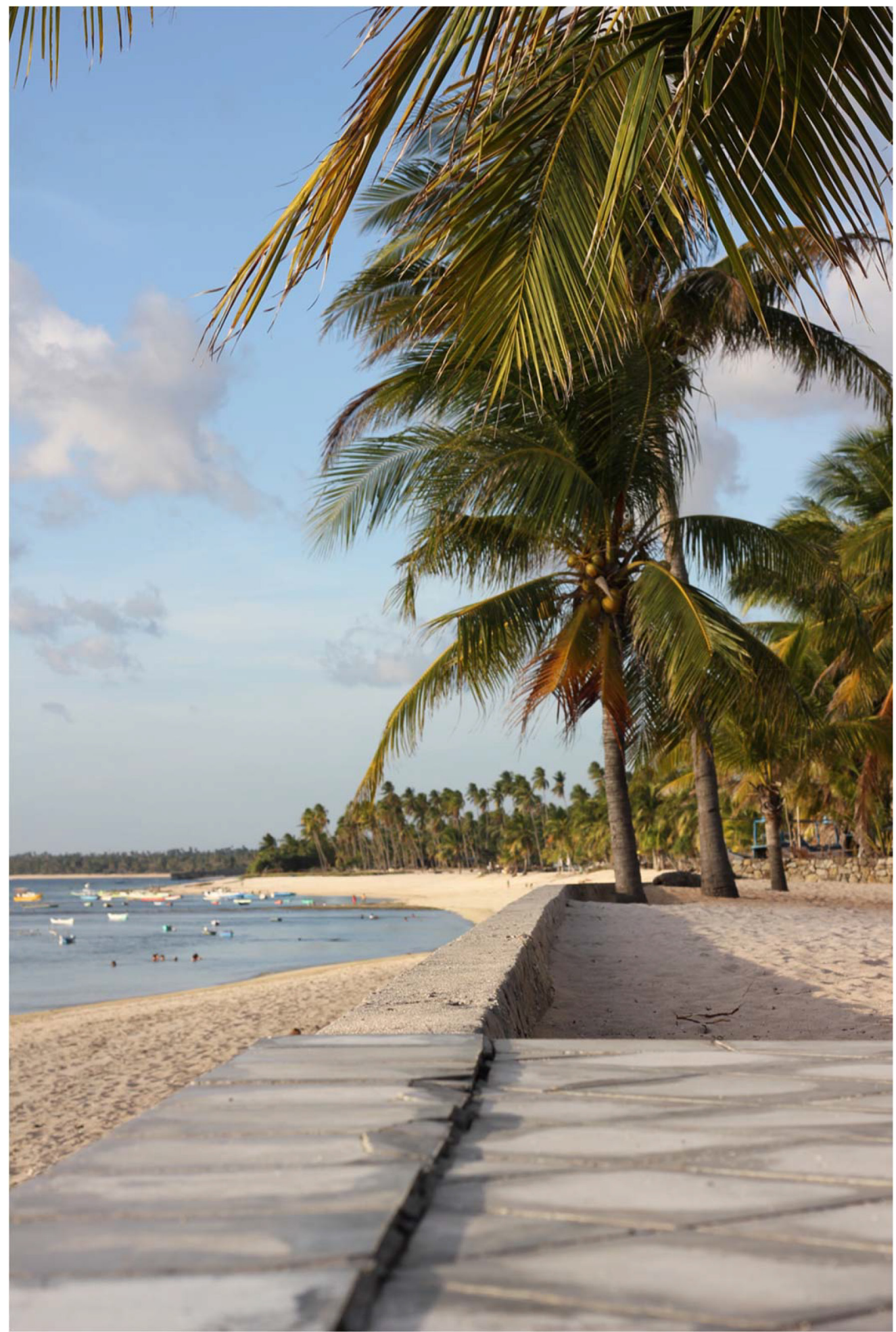

Figure 1 @illiam Kelly 


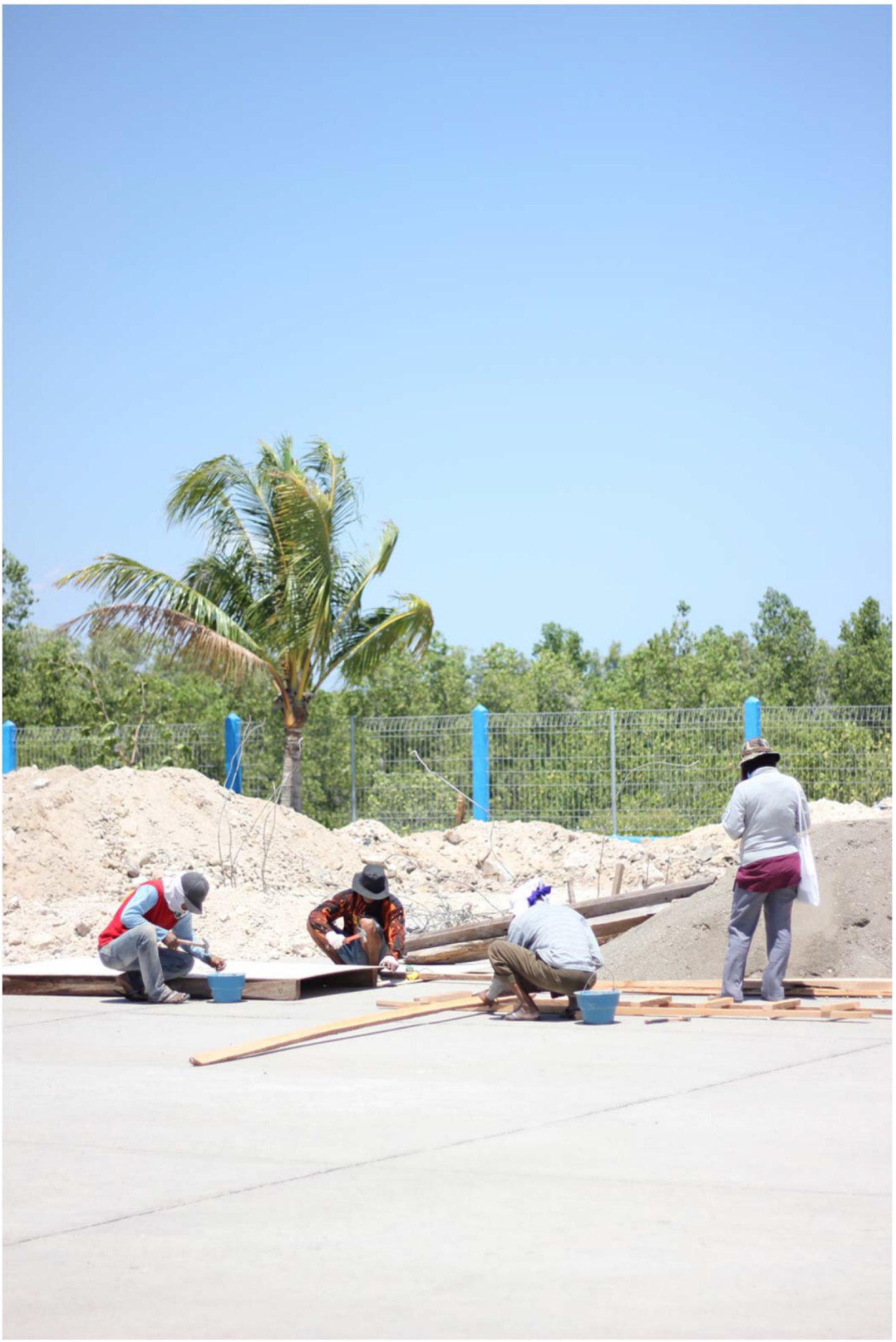

Figure 2 @illiam Kelly 
U T S

e P RESS

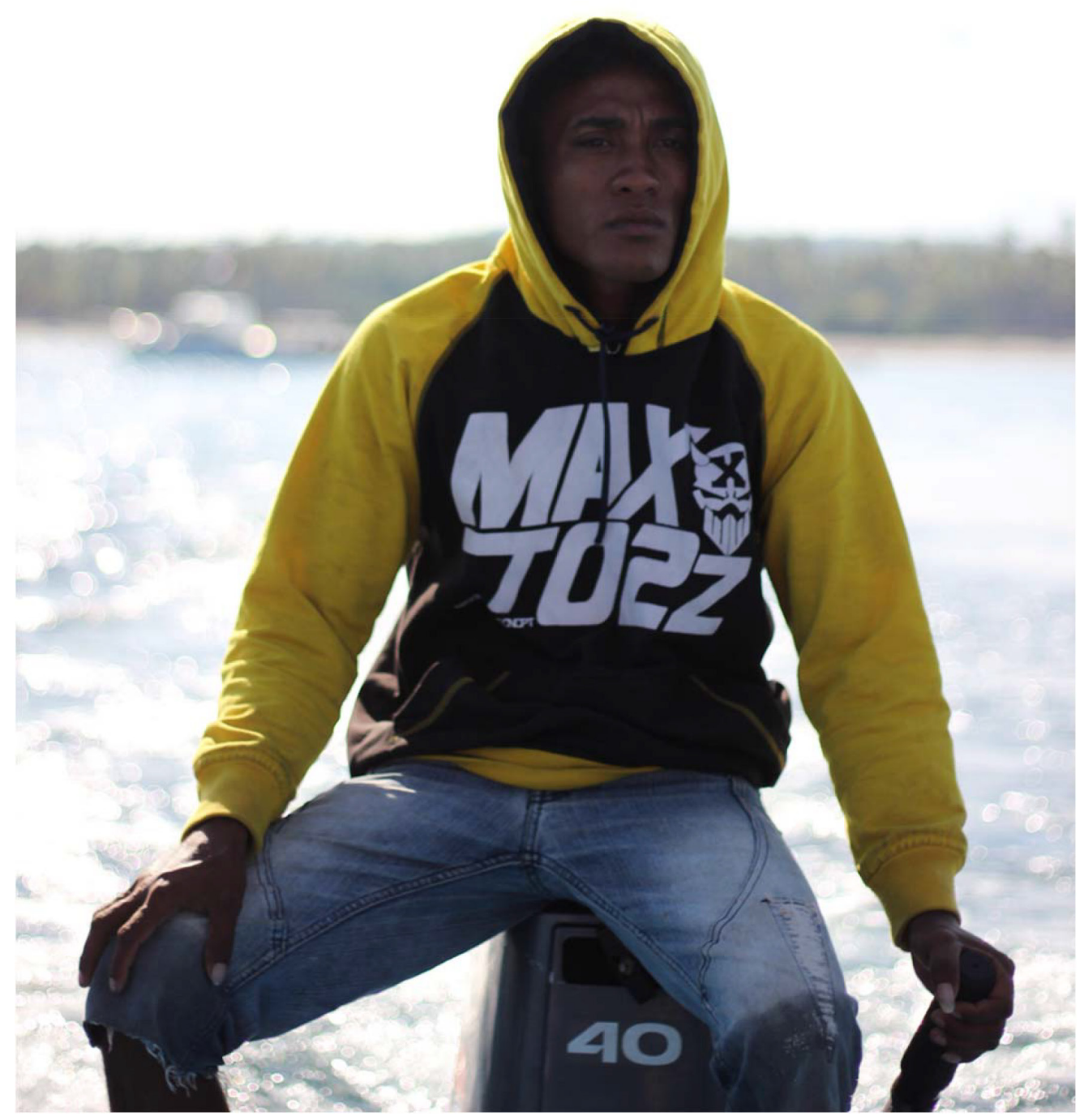

Figure 3 @ William Kelly 
U T S

e PRES S

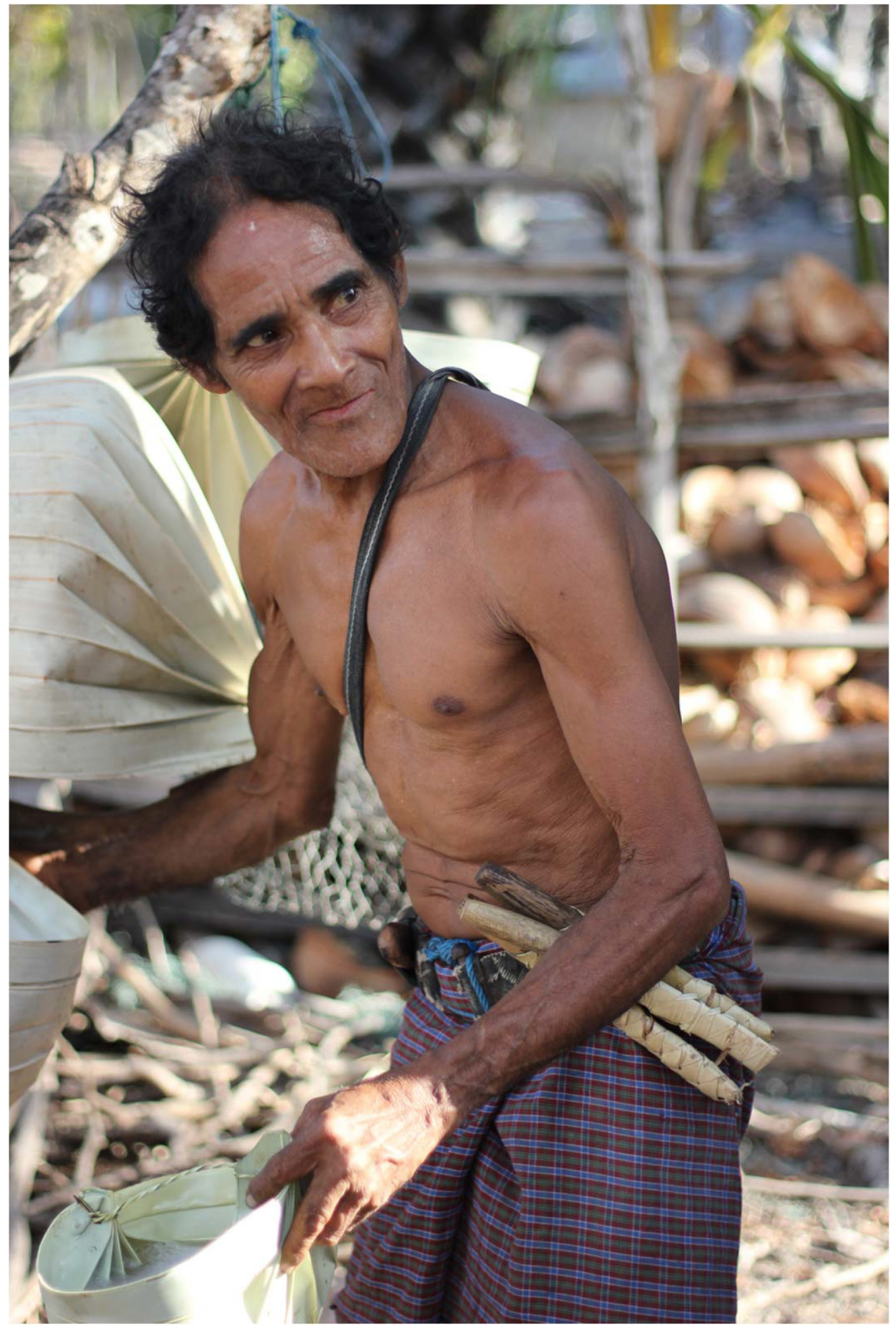

Figure 4 @ William Kelly 


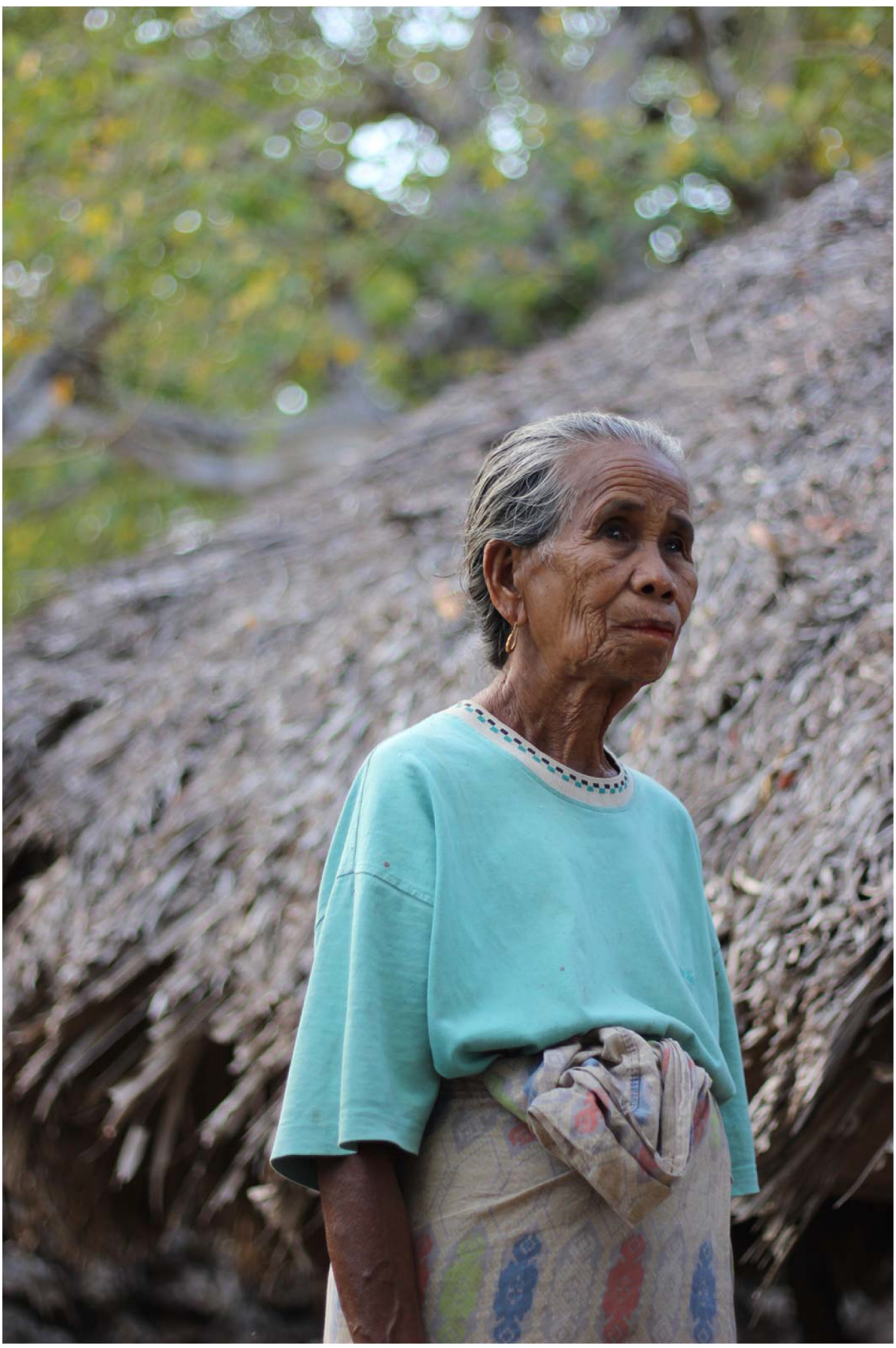

Figure 5 @ William Kelly 
U T S

e P RESS

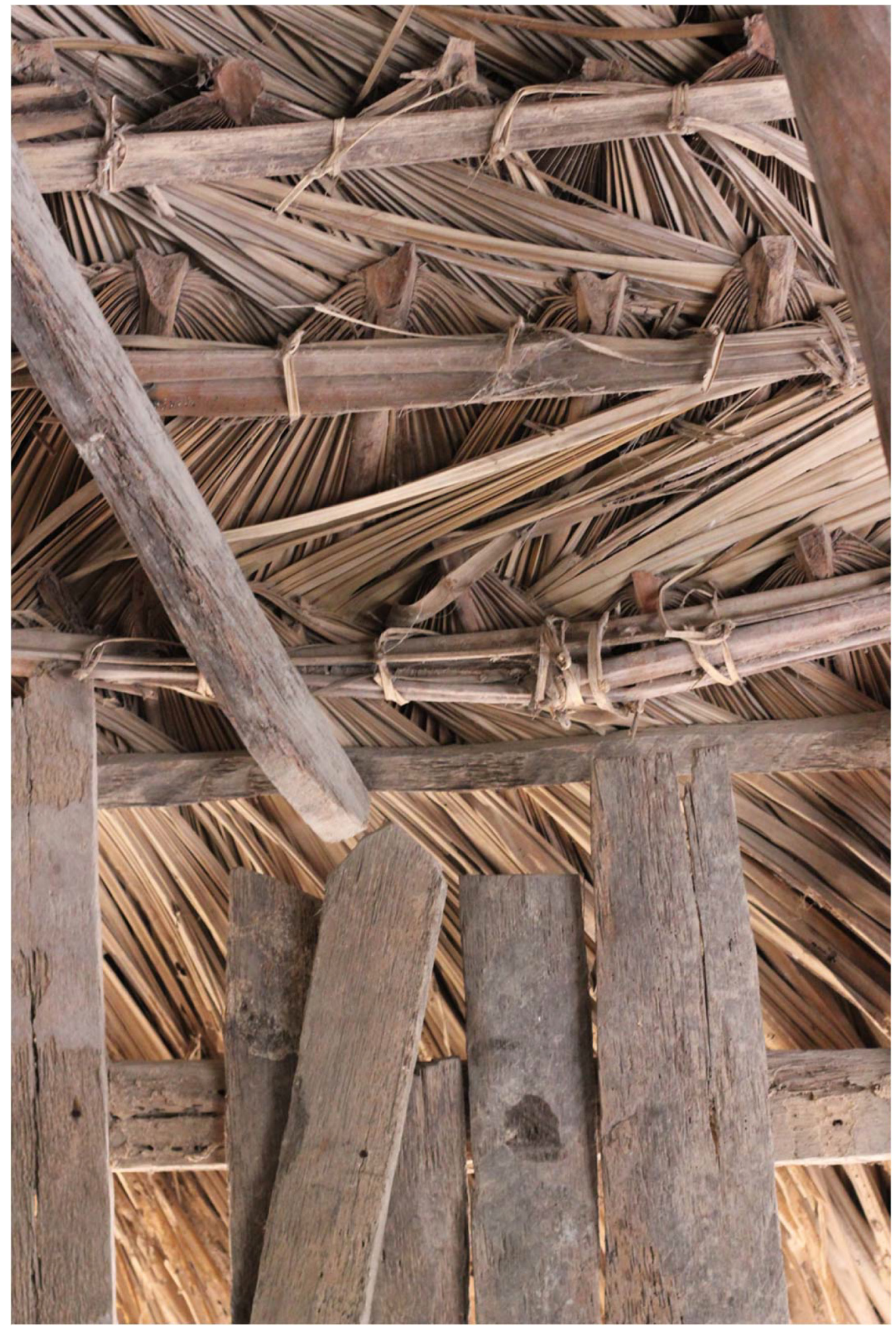

Figure 6 (c) William Kelly 
U T S

e P R E S S

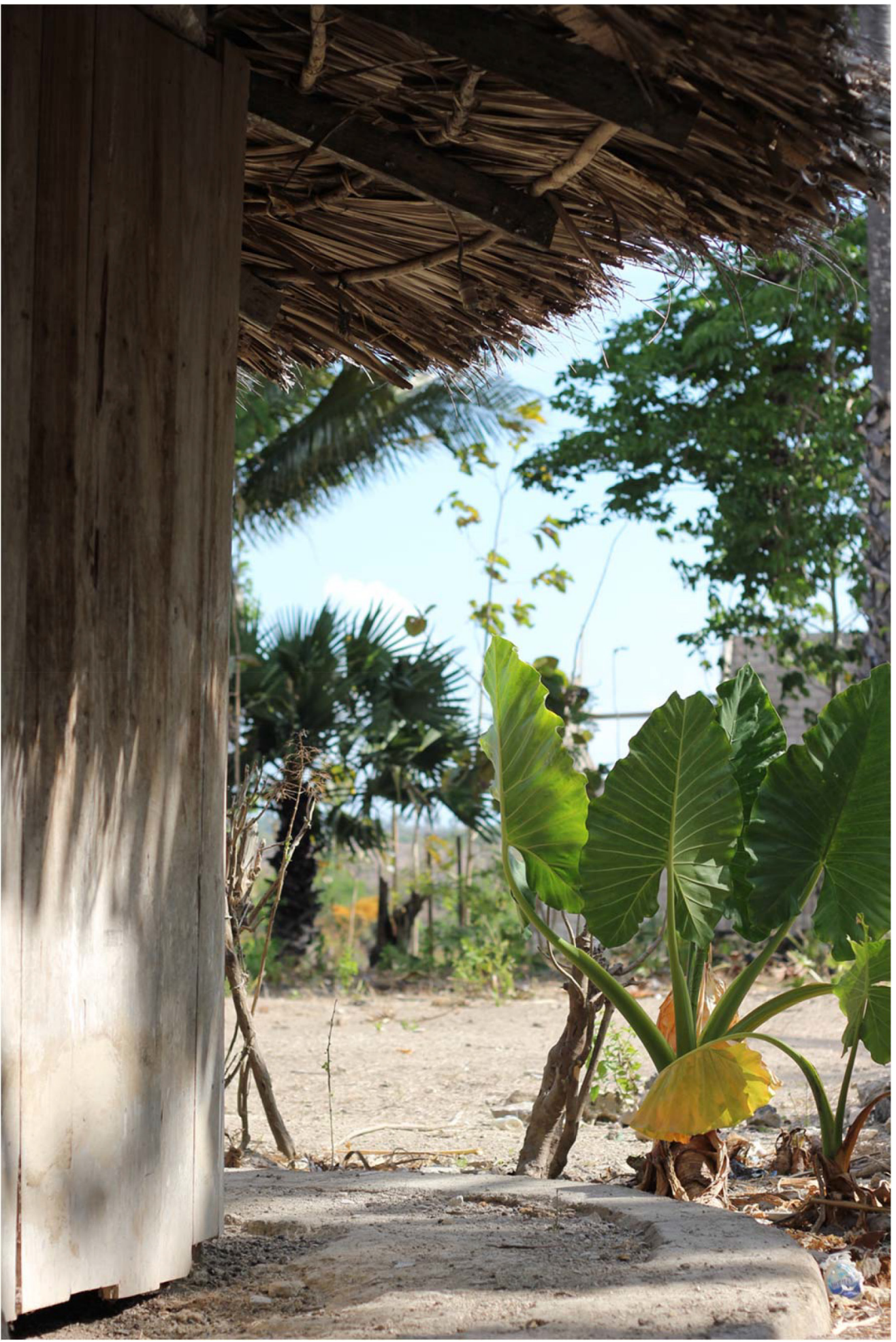

Figure 7 @ William Kelly 


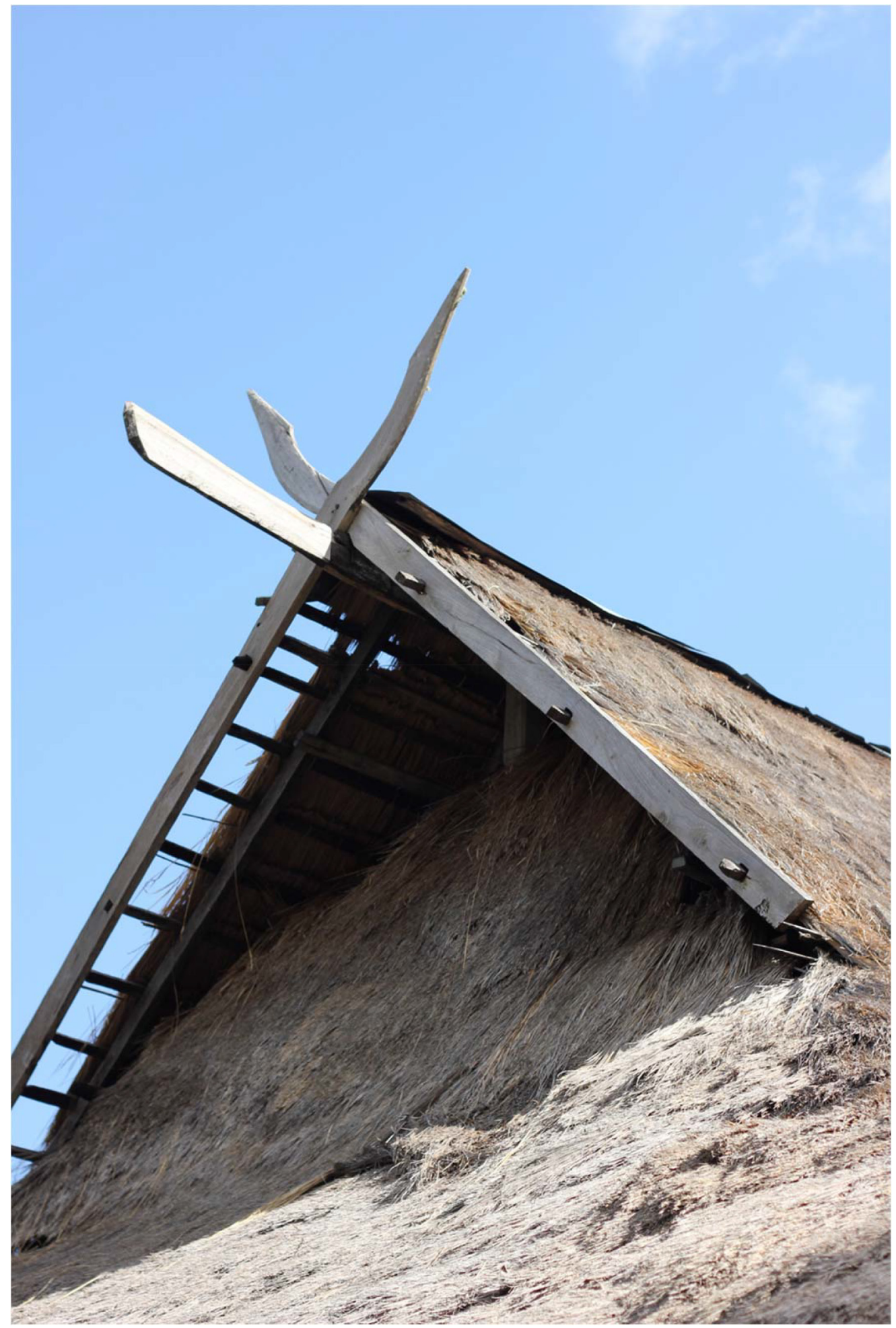

Figure 8 @ William Kelly 
U T S

e P R E S S

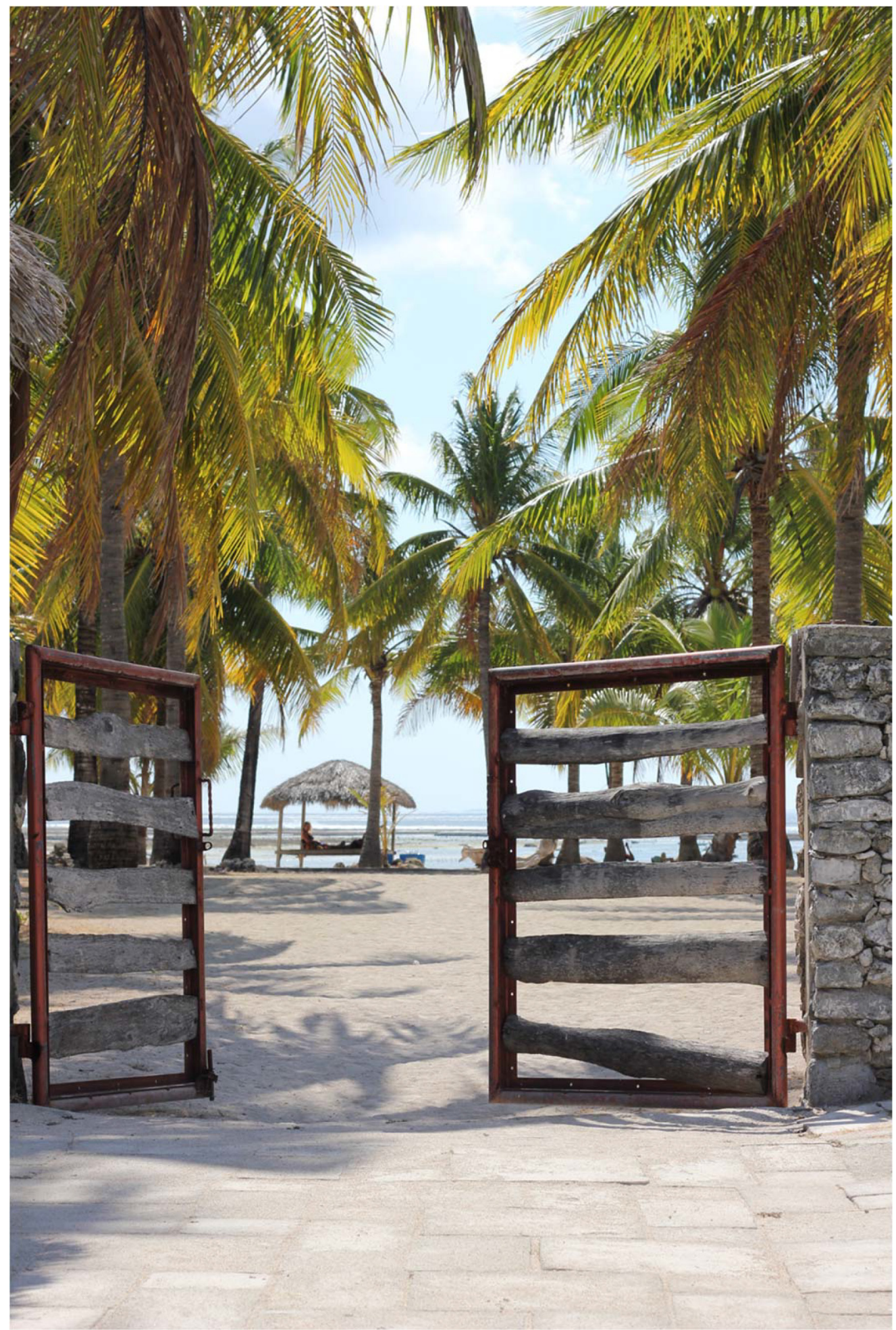

Figure 9 @ William Kelly 


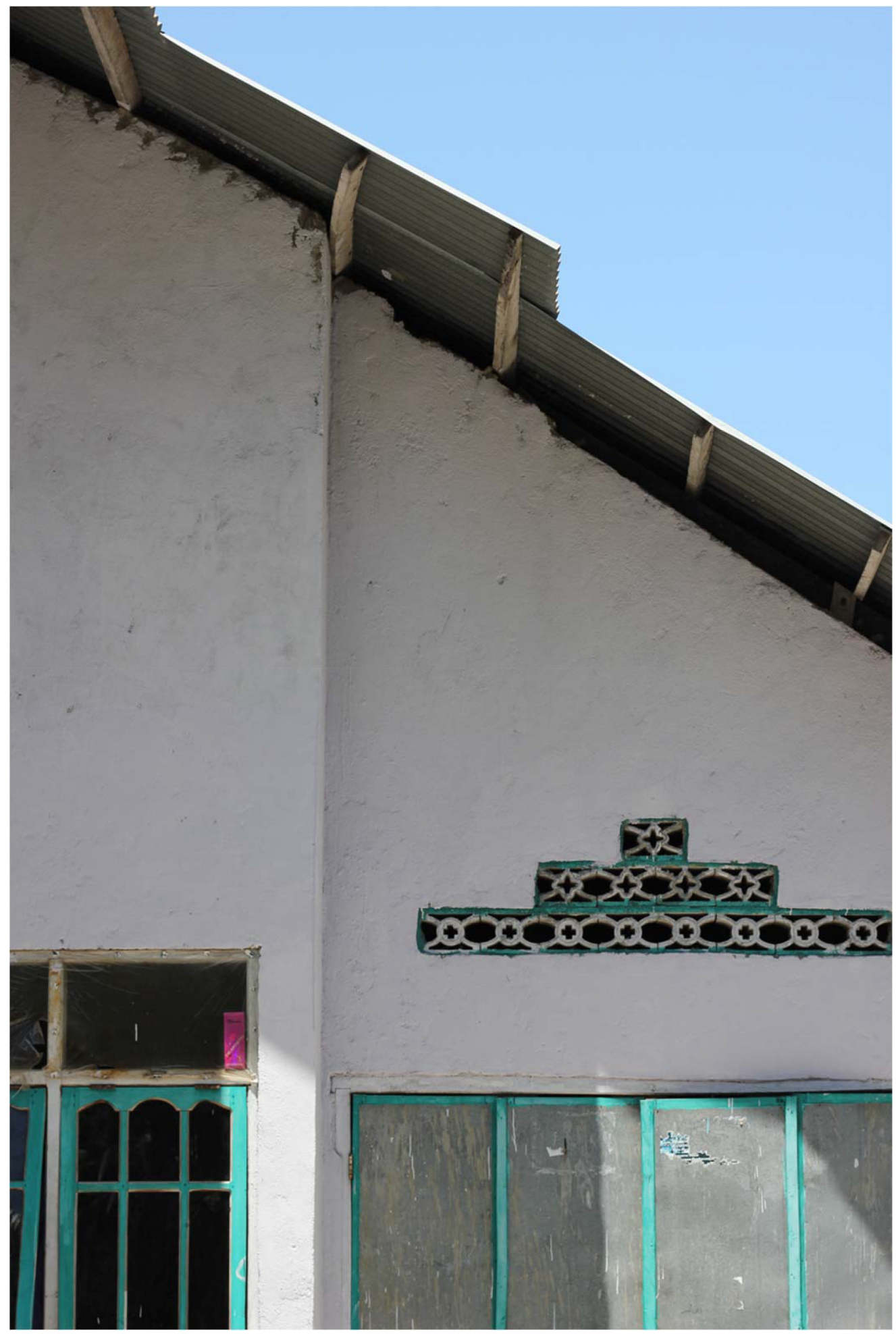

Figure 10 @ William Kelly 


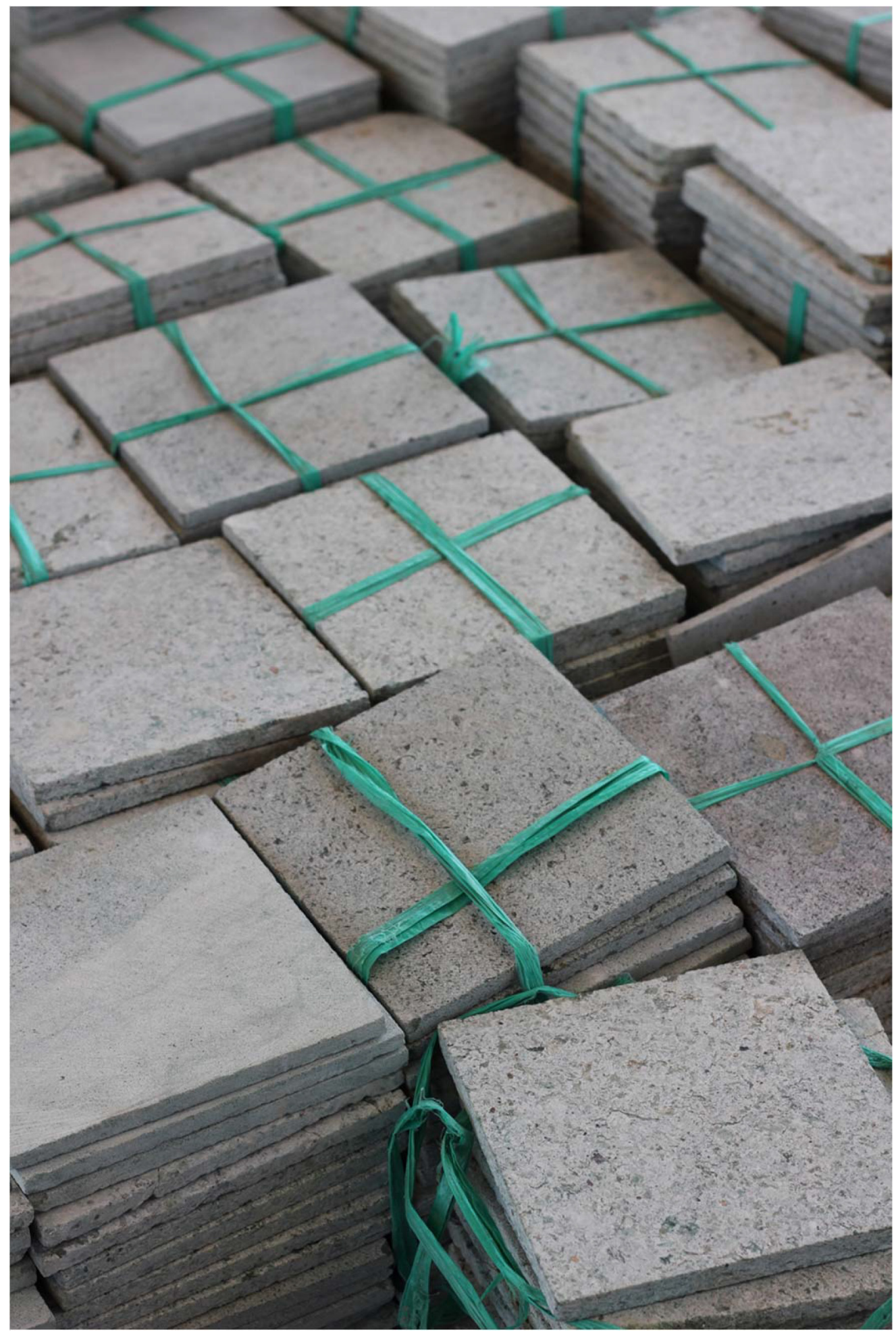

Figure 11 @ William Kelly 
U T S

e PRESS

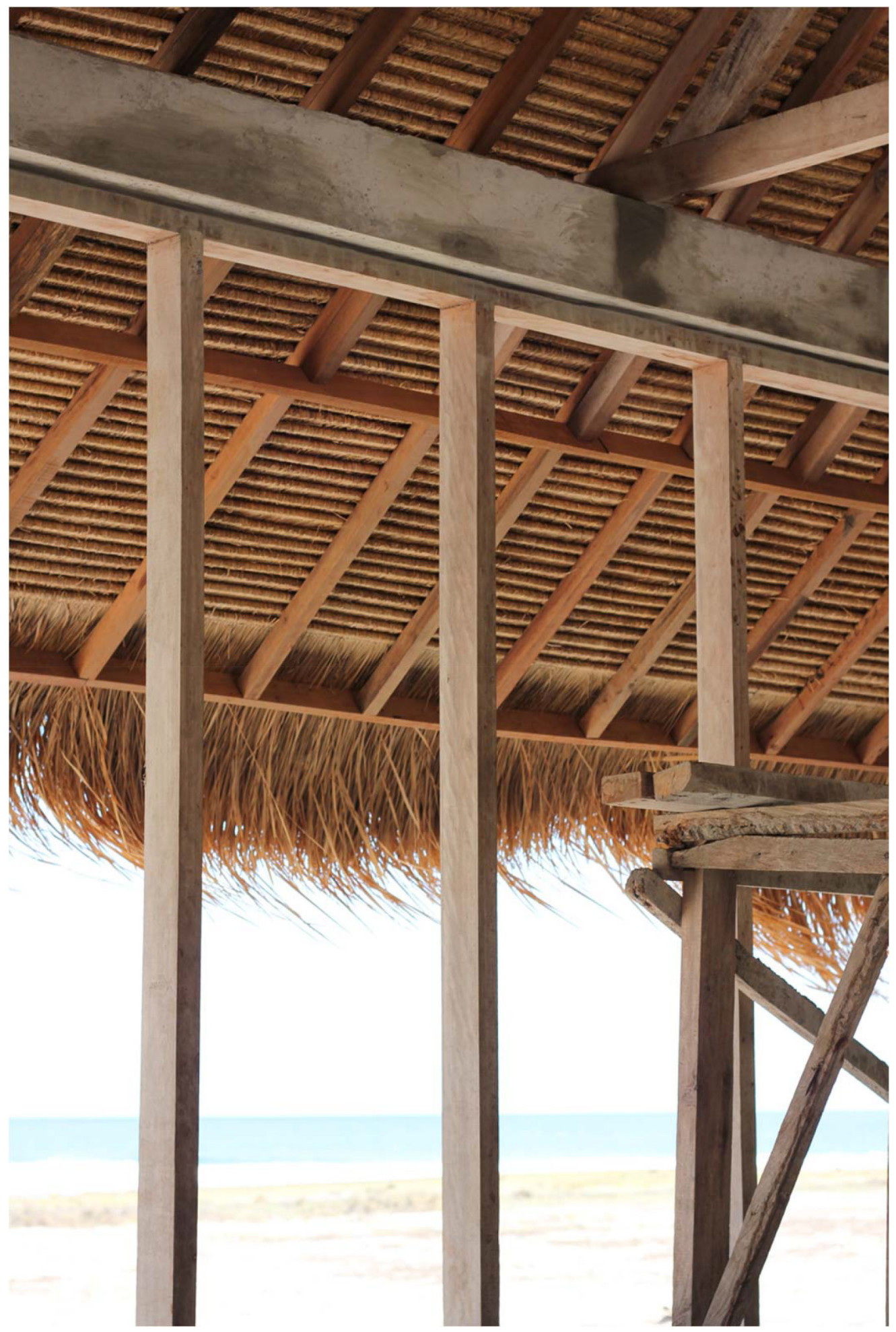

Figure 12 @ William Kelly 
U T S

e PRES S

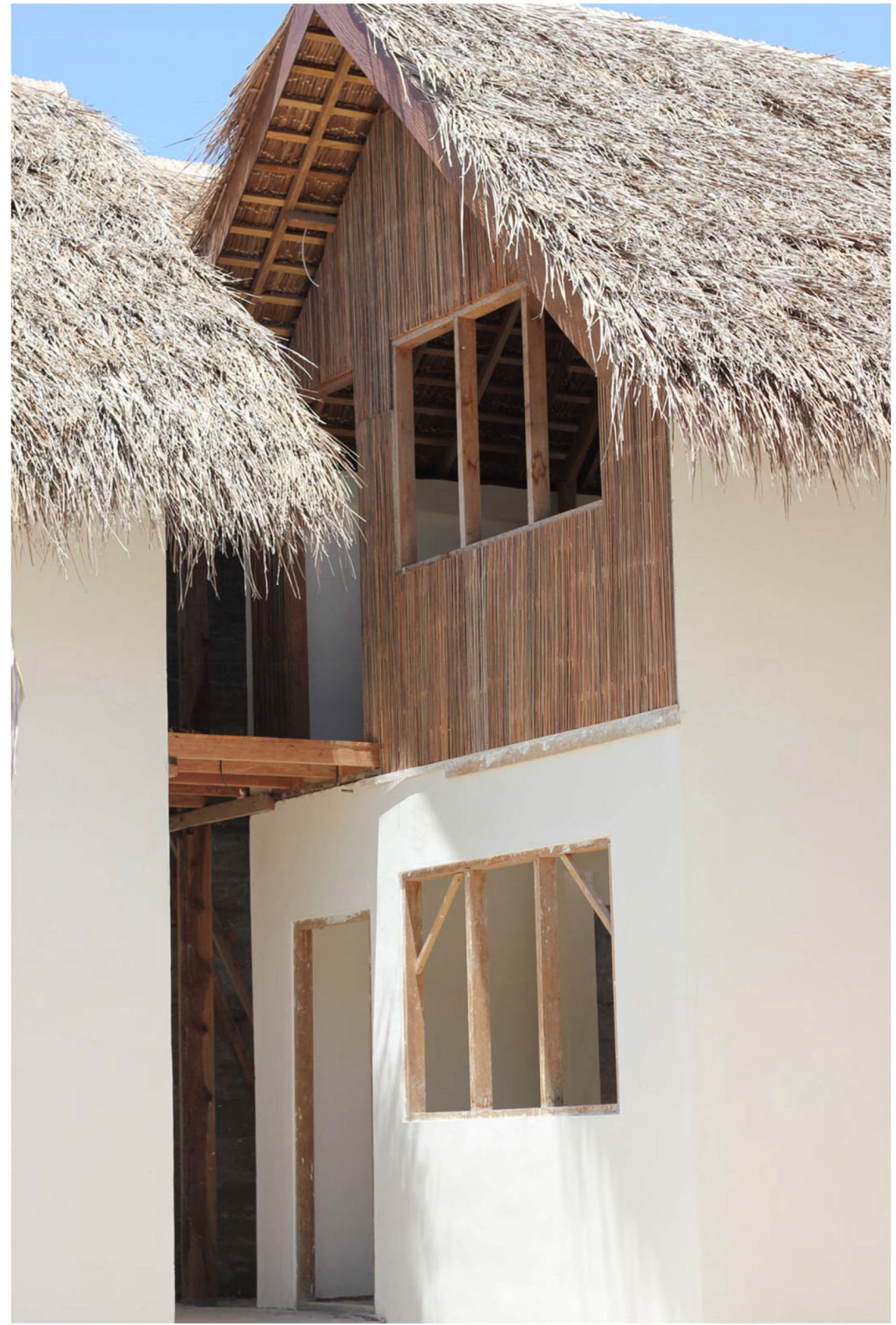

Figure 13 (c) William Kelly 


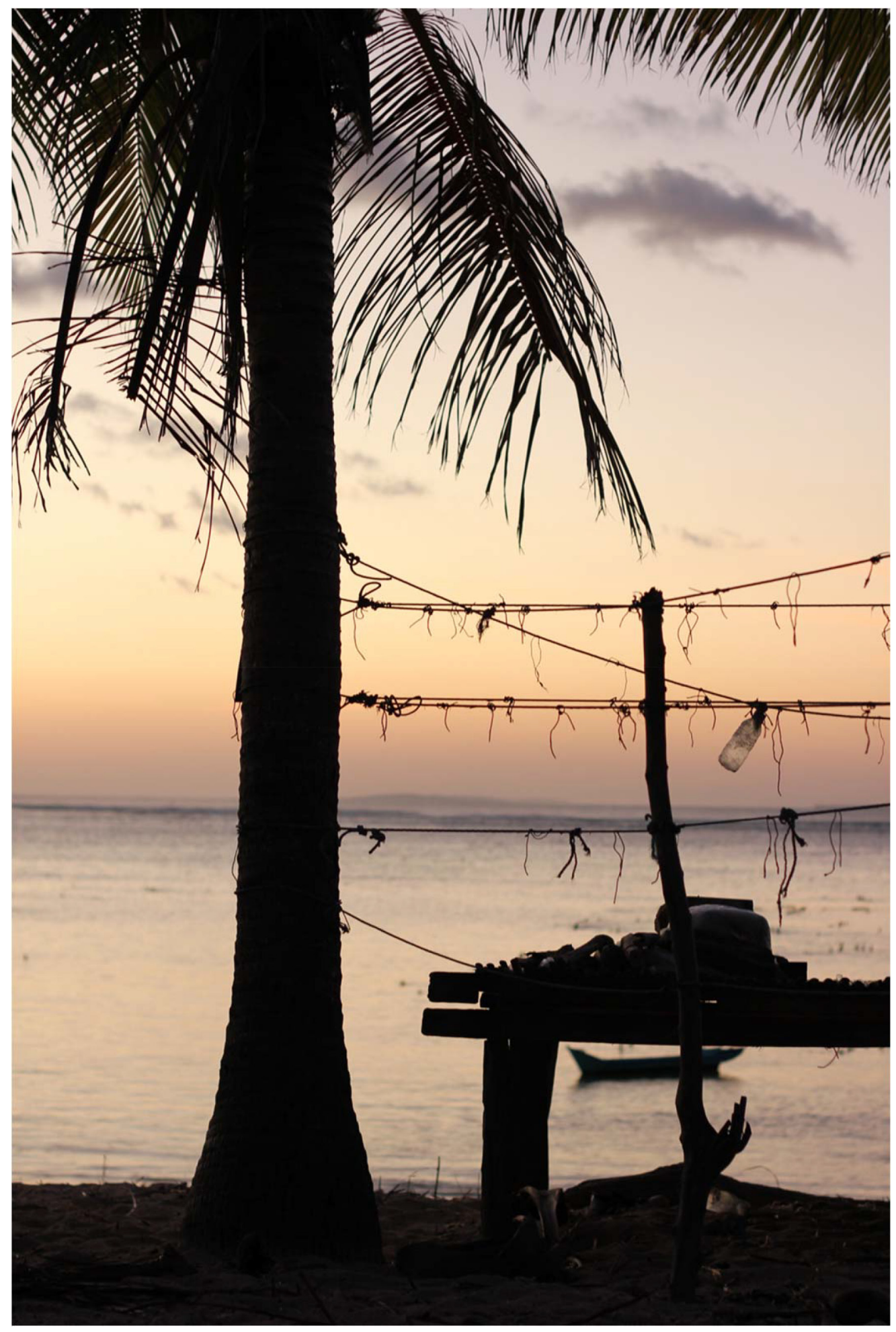

Figure 14 @ William Kelly 


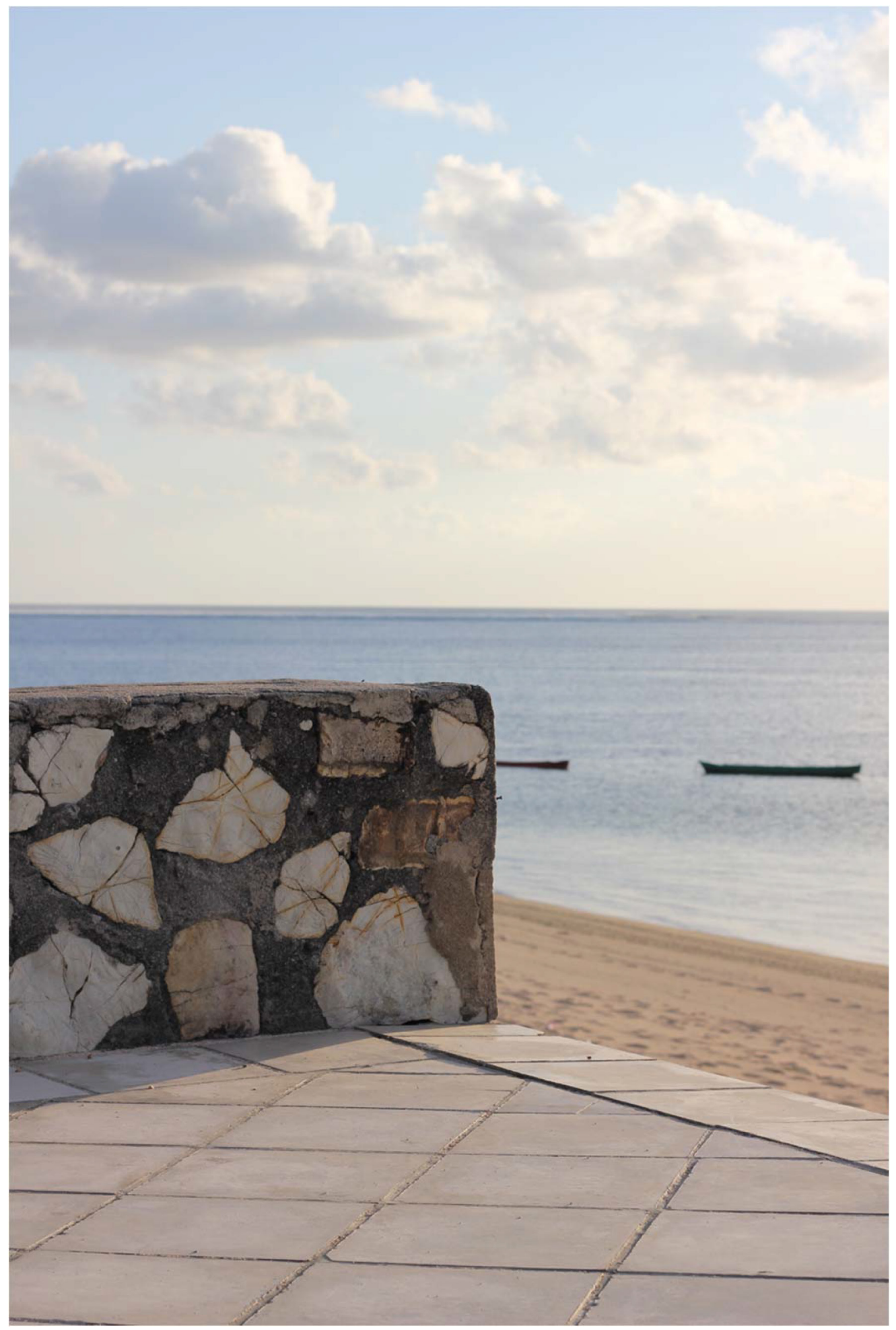

Figure $15 \odot$ William Kelly 
representatives, local elders, local researchers and residents from local and expatriate communities. Formalities were provided by local government representative and owner of the Anugerah Resort, Erasmus Frans, with translation and expert advise provided by expatriate architect Tom McAuliffe and his partner Sally May Mills. The discussion that took place throughout the presentations identified a string of pressing concerns.

Economically, it was noted that the unprecedented rate of tourism developments between 2010 and 2015 is seen as the cause of escalating costs of land, with direct impacts on the social fabric of local communities. Specific controversy—that surrounding the Boa Developmentrelated to the lack of transparency and public access to information pertaining to the specifics, extent and scale of this development relative to the lack of planning controls and the ambiguity surrounding setbacks from the high water mark. Whilst increased tourism was generally perceived to be a positive step, it was noted that the western region of Rote was not well equipped to manage increased waste production. Water shortages during the dry season are already a serious problem, one exacerbated by the relatively minor tourism infrastructure constructed to date.

With hard lessons learnt from the environmental impact of unsustainable tourism development in other parts of Indonesia (best exemplified by Bali), the concerns around foreign investment and tourism development constitute serious challenges for the environmental and social fabric of Rote Ndao. The series of photographs by William Kelly that are featured in this essay are proposed as a kind of provocation for further discussion and a call for both monitoring and moderating tourism development in Rote in the hope for the implementation of planning controls that could safeguard the pristine and unique quality of Western Rote. 